DOI: https://doi.org/10.36910/6775-2524-0560-2021-42-14

УДК: 004.056.5

Терейковська Людмила Олексіївна, к.т.н., доц.

http://orcid.org/0000-0002-8830-0790

Київський національний університет будівництва і архітектури

\title{
МЕТОД ФІЛЬТРАЦІЇ БІОМЕТРИЧНИХ ПАРАМЕТРІВ НА ОСНОВІ ВЕЙВЛЕТ-ПЕРЕТВОРЕНЬ
}

Л. Терейковська. Метод фільтрації біометричних параметрів на основі вейвлет-перетворень. Стаття присвячена проблемі вдосконалення засобів прихованого моніторингу особи та емоцій операторів інформаційно-управляючих систем на основі біометричних параметрів, що співвідносяться 3 двовимірними зображеннями та характеризуються за допомогою геометричних показників. 3'ясовано, що труднощі розробки таких засобів багато в чому пов'язані 3 очищенням підконтрольних зображень від типових нестаціонарних завад, викликаних нерівномірністю освітлення та сторонніми предметами, що заважають відеореєстрації. Запропоновано нівелювати означені труднощі за рахунок застосування технології вейвлет-перетворень, котра використовується для фільтрації зображень шляхом об'єднання декількох однакових, але різним чином зашумлених бінарних, півтонових та кольорових зображень. Розроблено метод фільтрації, який за рахунок застосування запропонованого підходу до застосування вейвлет-перетворень відеоряду послідовно зареєстрованих біометричних параметрів, дозволяе з задовільною якістю реалізовувати їх очищення від типових нестаціонарних завад. Проведені експериментальні дослідження показали доцільність застосування розробленого методу для фільтрації зображень обличчя та радужної оболонки ока операторів інформаційно-управляючих систем.

Ключові слова: розпізнавання емоцій, автентифікація, інформаційно-управляюча система, біометричний параметр, вейвлет-перетворення, захист інформації.

Л. Терейковская. Метод фильтрации биометрических параметров на основе вейвлет-преобразований. Статья посвящена проблеме совершенствования средств скрытого мониторинга лица и эмоций операторов информационноуправляющих систем на основе биометрических параметров, которые соотносятся с двумерными изображениями и характеризуются геометрическими показателями. Выяснено, что трудности разработки таких средств во многом связаны с очисткой подконтрольных изображений от типичных нестационарных помех, вызванных неравномерностью освещения и посторонними предметами, которые препятствуют видеорегистрации. Предложено нивелировать указанные трудности за счет применения технологии вейвлет-преобразований, которая используется для фильтрации изображений путем объединения нескольких одинаковых, но различным образом зашумленных бинарных, полутоновых и цветных изображений. Разработан метод фильтрации, который за счет применения предложенного подхода к применению вейвлет-преобразований видеоряда последовательно зарегистрированных биометрических параметров, позволяет с удовлетворительным качеством реализовывать их очистку от типовых нестационарных помех. Проведенные экспериментальные исследования показали целесообразность применения разработанного метода для фильтрации изображений лица и радужной оболочки глаза операторов информационно-управляющих систем.

Ключевые слова: распознавание эмоций, аутентификация, информационно-управляющая система, биометрический параметр, вейвлет-преобразование, защита информации.

L. Tereikovska. Method for filtering biometric parameters based on wavelet transforms. The article is devoted to the problem of improving the means of hidden monitoring of the face and emotions of operators of information and control systems based on biometric parameters that correlate with two-dimensional images and are characterized by geometric indicators. It was found that the difficulties in the development of such tools are largely associated with cleaning the controlled images from typical non-stationary interference caused by uneven illumination and foreign objects that impede video recording. It is proposed to neutralize these difficulties by applying the technology of wavelet transformations, which is used to filter images by combining several identical but differently noisy binary, grayscale and color images. A filtering method has been developed, which, due to the application of the proposed approach to the application of wavelet transformations of the video sequence of sequentially recorded biometric parameters, allows them to be cleaned from typical non-stationary interference with satisfactory quality. Experimental studies have shown the feasibility of using the developed method for filtering images of the face and iris of the operator of information control systems.

Keywords: emotion recognition, authentication, information management system, biometric parameter, wavelet transform, information security.

Постановка наукової проблеми. В сучасних умовах розробка засобів прихованого моніторингу (ЗПМ) особи та емоцій операторів інформаційно-управляючих систем (ІУС) на основі біометричних параметрів є однією із тих задач, вирішення яких дозволить суттєво підвищити як ефективність виявлення спроб несанкціонованого доступу до інформації, так і ефективність оцінки адекватності психоемоційного стану персоналу щодо можливості вирішення поставлених перед ними функціональних обов'язків $[1,6,8,16]$. Вказані засоби 3 успіхом використовуються в офісних інформаційних системах для захисту від інсайдерів, в системах дистанційного навчання для автоматичного управління режимом подачі учбових матеріалів та для перевірки справжності особи студента при здачі іспитів. Крім того засоби дистанційного автоматичного моніторингу емоційного стану можуть стати в нагоді в системах виявлення порушень правопорядку в громадських місцях та в інформаційних системах автоматичного моніторингу психоемоційного стану хворих.

В більшості випадків теоретичним підгрунтям ЗПМ особи та емоцій $є$ нейромережевий аналіз таких біометричних параметрів як зображення обличчя та зображення райдужної оболонки ока, тобто 
біометричних параметрів, котрі співвідносяться з двовимірними зображеннями та характеризуються за допомогою геометричних показників [10, 20-23]. Це пояснюється доступністю засобів реєстрації, високою спорідненістю вказаних біометричних параметрів 3 особою та емоціями людини, апробованістю нейромережевих рішень та наявністю доступних репрезентативних маркованих баз даних зображень обличчя та зображень райдужної оболонки ока, що значно спрощує процес розробки нейромережевих моделей. Разом з тим на практиці ефективність ЗПМ в значній мірі залежить від якості реєстрації зображення обличчя та зображення райдужної оболонки ока, що пояснюється наявністю типових завад, які неможливо нівелювати шляхом підвищення характеристик апаратного забезпечення [14, 23-25] .

Таким чином пояснюється актуальність науково-практичної задачі вдосконалення методів фільтрації біометричних параметрів, котрі співвідносяться 3 двовимірними зображеннями та використовуються в біометричних нейромережевих ЗПМ особи та емоцій операторів ІУС.

Аналіз останніх досліджень i публікацій. Як показують результати аналізу науковопрактичних робіт $[3,23,26]$, одним із основних напрямків розвитку нейромережевих засобів розпізнавання особи та емоцій людини по зображенню обличчя та зображенню райдужної оболонки ока $є$ підвищення пристосованості вказаних засобів до очікуваних умов експлуатації при виникненні типових завад. Разом з тим в роботах $[12,18,24]$ відзначено, що типові завади, котрі значно ускладнюють процес розпізнавання, в основному викликані:

- наявністю предметів, що закривають частину зображення,

- нерівномірністю освітлення, що призводить до відблисків на зображенні.

При цьому в багатьох випадках локалізація та інші параметри типових завад мають нестаціонарний динамічний характер.

Для прикладу на рис. 1 показано спотворені під впливом типових завад зображення обличчя та зображення райдужної оболонки ока.

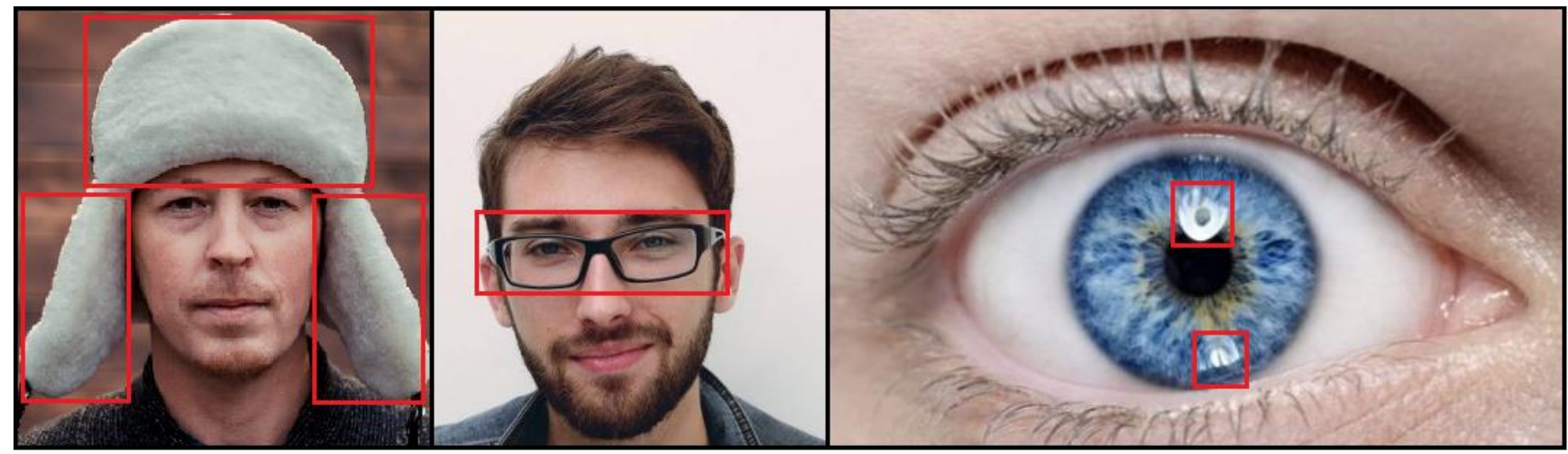

Рис. 1. Спотворені під впливом типових завад зображення обличчя та зображення райдужної оболонки ока

На рис. 1 показані типові завади, до яких відносяться шапка, окуляри та відблиски світла. Зазначимо, що не зважаючи на природу завад, їх негативний вплив полягає у тому, що на зображенні з'являються ділянки, котрі власне і спотворюють зображення. Для нівелювання такого впливу в роботах [2-6] пропонується використовувати різні методи локальної фільтрації та сегментації зображень.

В роботах $[3,14]$ наведено критичний огляд таких методів фільтрації та сегментації. Відзначено, що в результаті фільтрації характеристики яскравості кожної точки цифрового зображення замінюються іншим значенням яскравості, котре в меншій мірі спотворене перешкодою. При цьому методи фільтрації розділяються на:

- просторові,

- частотні.

Просторові методи фільтрації зображень передбачають представлення растрового зображення у вигляді двовимірної матриці, що дозволяє застосування до кожної точки зображення операції згортки. Так, в роботі [7] наведено спосіб очищення від шуму за рахунок застосування згладжувальних фільтрів для очистки зображень у відтінках сірого. Проведено порівняння ефективності різних типів згладжувальних фільтрів. За допомогою комп'ютерних експериментів показано, що для слабкозашумлених зображень найбільш ефективним $\epsilon$ фільтр Гауса розмірністю $5 \times 5$. Відзначається, що просторові методи фільтрації можливо ефективно застосовувати для покращення якості зображень, 
однак їх застосування малоефективне для нівелювання завад, що викликані спотворенням частини зображення. В цьому випадку більш ефективними вважаються частотні методи фільтрації.

Класичні частотні методи фільтрації базуються на спектральному аналізі зображень 3 використанням дискретного перетворення Фур'є. Недоліки таких методів викликані обмеженнями методу Фур'є, що призводять до складності локалізації частотних показників спектру у часі $[11,15]$.

Виправлення вказаного недоліку пов'язують із застосуванням методів фільтрації, що базуються на вейвлет-перетвореннях [2, 4, 17]. Наприклад, в роботі [9] розглянута математична модель параметризації структури райдужної оболонки ока з використанням вейвлет-перетворення на основі похідних функції Гауса. Наведено результати експериментальних досліджень, що доводять ефективність запропонованої моделі.

В роботах $[5,13,19]$, що присвячена аналізу способів використання вейвлет-перетворень в області кодування зображень, визначено перелік вимог, виконання яких забезпечує ефективність означеного процесу. Вказані вимоги співвідносяться з можливістю:

- кратномасштабного аналізу зображення,

- просторової локалізації,

- ортогональності,

- реалізації алгоритму обчислень з низькою обчислювальною складністю,

- застосування апробованих інструментальних засобів.

Аналіз робіт $[2,4,5,13]$ дозволяє стверджувати, що в більшості випадків в якості базисного вейвлету при фільтрації зображень використовують вейвлети HAAR, MHAT, FHAT, WAVE, GABOR, Daubechies wavelet, які визначаються виразами виду (1-6)

$$
\begin{gathered}
\varphi(x)=\left\{\begin{array}{c}
1, x \in[0,0,5] \\
-1, x \in[0,5,1], \\
0, x \in[0,1]
\end{array}\right. \\
\varphi(x)=\frac{2}{\sqrt{3}} \pi^{-0,25}\left(1-x^{2}\right) e^{-0,5 x^{2}}, \\
\varphi(x)=\left\{\begin{array}{c}
\left.1, x \in]-\infty, \frac{1}{3}\right] \\
\left.-0,5, x \in] \frac{1}{3}, 1\right], \\
0, x \in] 1, \infty[
\end{array}\right. \\
\varphi(x)=x e^{-0,5 x^{2}}, \\
\varphi(x)=e^{-\left(x-x_{0}\right)^{2} / a^{2}} e^{-i k_{0}\left(x-x_{0}\right)}, \\
\varphi(x)=\sqrt{2} \sum_{k} g_{k} \phi(2 x-k) .
\end{gathered}
$$

Результати проведеного аналізу дозволяють стверджувати, що хоча застосуванню вейвлетперетворень в області фільтрації зображень присвячено багато робіт, однак застосування отриманих результатів для фільтрації біометричних параметрів, котрі характеризуються за допомогою геометричних показників, ускладнюється необхідністю складної адаптації до нестаціонарного динамічного характеру зміни параметрів типових завад. Виправити вказаний недолік можливо, по аналогії $з$ [21], за рахунок розробки методу застосування вейвлет-перетворень для фільтрації вказаних параметрів, що і зумовлює мету даного дослідження.

Мета дослідження. Розробка методу фільтрації біометричних параметрів, що за рахунок застосування технології вейвлет-перетворень забезпечить очищення зображення обличчя та зображення райдужної оболонки ока від типових нестаціонарних завад.

\section{Виклад основного матеріалу й обгрунтування отриманих результатів.}

Біометричний параметр, котрий характеризується геометричними показниками, по суті представляє собою цифрове зображення, що $є$ дискретним двовимірним сигналом. Відповідно рекомендацій $[2,9,11]$, представити такий сигнал доцільно за допомогою двовимірної прямокутної або квадратної матриці. Тому для аналізу таких сигналів прийнято використовувати двовимірне дискретне вейвлет-перетворення, яке є композицією одновимірних дискретних вейвлет-перетворень.

На кожному етапі деталізації спочатку одновимірні дискретні вейвлет-перетворення застосовуються для кожного рядка двовимірної матриці вхідних даних. Після цього виконуються одновимірні вейвлет-перетворення для кожного стовпця отриманої матриці.

Математичний апарат для розрахунку матриці вейвлет-коефіцієнтів одного рядка пікселів кольорового зображення визначається виразами виду:

$$
\left\{\begin{array}{c}
\boldsymbol{W}_{m, k}=\frac{1}{\sqrt{a_{0}^{m}}} \sum_{n=0}^{N-1}\left(q\left(x_{n}\right) \varphi^{*}\left(a_{0}^{m} x_{n}-k\right)\right) \\
1 \leq m, k \leq N
\end{array}\right.
$$




$$
q=0,299 R+0,587 G+0,114 B
$$

де $a_{0}$ - початковий масштаб, $k$ - параметр зсуву, $m$ - параметр масштабу, $x_{n}$ - координата n-ої точки зображення, * - операція комплексного спряження, $N$ - розмір зображення, $q\left(x_{n}\right)$ - величина закодованого кольору зображення в точці $x_{n}, \varphi$ - базисний вейвлет виду (1-6), R, G, B - компоненти кожного із каналів кольору в форматі RGB для окремого пікселя.

Зазначимо, що вирази $(7,8)$ використовуються у випадку, коли при обробці зображення його кольором можливо знехтувати. У випадку, коли це реалізувати не доцільно, вейвлет-коефіцієнти розраховуються окремо для кожного із кольорових каналів. Відповідний математичний апарат можливо записати так:

$$
\left\{\begin{array}{c}
\boldsymbol{W}_{m, k}(i)=\frac{1}{\sqrt{a_{0}^{m}}} \sum_{n=0}^{N-1}\left(q\left(x_{n}, i\right) \varphi^{*}\left(a_{0}^{m} x_{n}-k\right)\right), \\
1 \leq m, k \leq N
\end{array},\right.
$$

де $q\left(x_{n}, i\right)$ - інтенсивність і-го каналу кольору в точці $x_{n}$. кольором.

При використанні RGB-моделі канали співвідносяться 3 червоним, зеленим та блакитним

Власне процедура фільтрації полягає у вилученні визначених компонент матриці $\boldsymbol{W}_{m, k}$. В більшості випадків вилучаються ті компоненти матриці $\boldsymbol{W}_{m, k}$, для яких параметр зсуву та/або параметр масштабу виходять за межі наперед визначеного діапазону. Після цього компоненти відфільтрованої матриці $\boldsymbol{W}_{m, k}$ використовуються в процедурі оберненого вейвлет-перетворення для відновлення очищеного зображення. Для монокольорового зображення використовується вираз (10), для багатокольорового зображення - вираз (11).

$$
\begin{aligned}
& q\left(x_{n}\right)=\frac{\pi}{\ln \left(a_{0}\right)} \sum_{n=0}^{N-1} \sum_{k=0}^{N-1}\left(\varphi^{*}\left(x_{n}\right) \boldsymbol{W}_{m . k}\right), \\
& q\left(x_{n}, i\right)=\frac{\pi}{\ln \left(a_{0}\right)} \sum_{n=0}^{N-1} \sum_{k=0}^{N-1}\left(\varphi^{*}\left(x_{n}\right) \boldsymbol{W}_{m . k}(i)\right),
\end{aligned}
$$

де $i$ - номер кольорового каналу.

Базуючись на сформованих в $[5,13,19]$ вимогах, які забезпечують ефективність вейвлетперетворень, визначено доцільність використання діадного дискретного вейвлет-перетворення, що за рахунок зменшення кількості копій базисного вейвлету дозволяє зменшити обчислювальну складність процедури обчислення вейвлет-коефіцієнтів. Застосування діадного дискретного вейвлетперетворення призводить до модифікації виразів (7, 9-11):

$$
\begin{gathered}
\left\{\begin{array}{c}
\boldsymbol{W}_{m, k}=\frac{1}{\sqrt{2^{m}}} \sum_{n=0}^{N-1}\left(q\left(x_{n}\right) \varphi^{*}\left(2^{m} x_{n}-k\right)\right), \\
1 \leq m, k \leq N
\end{array}\right. \\
\left\{\begin{array}{c}
\boldsymbol{W}_{m, k}(i)=\frac{1}{\sqrt{2^{m}}} \sum_{n=0}^{N-1}\left(q\left(x_{n}, i\right) \varphi^{*}\left(2^{m} x_{n}-k\right)\right), \\
1 \leq m, k \leq N
\end{array}\right. \\
q\left(x_{n}\right)=\frac{\pi}{\ln (2)} \sum_{n=0}^{N-1} \sum_{k=0}^{N-1}\left(\varphi^{*}\left(x_{n}\right) \boldsymbol{W}_{m . k}\right), \\
q\left(x_{n}, i\right)=\frac{\pi}{\ln (2)} \sum_{n=0}^{N-1} \sum_{k=0}^{N-1}\left(\varphi^{*}\left(x_{n}\right) \boldsymbol{W}_{m . k}(i)\right) .
\end{gathered}
$$

Труднощі створення ефективних фільтрів багато в чому пов'язані з складністю розрахунку меж діапазонів, які визначають перелік компонентів матриці $\boldsymbol{W}_{m, k}$, котрі підлягають вилученню. Це пояснюється динамічним характером завад для одного і того ж об’єкту в різні моменти часу реєстрації біометричних параметрів. Наприклад, як це показано на рис. 2 , в момент часу $t_{1}$ в лівому нижньому куті райдужної оболонки ока виникає завада типу «відблиск», пов'язана з нерівномірністю освітлення. В момент часу $t_{2}$ через зміну освітлення подібна завада виникає вже у правому верхньому куті райдужної оболонки ока.
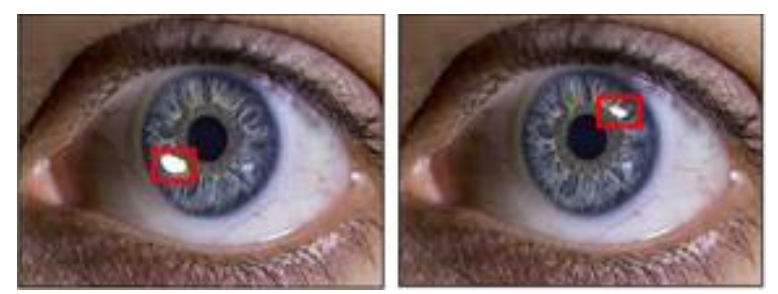

Рис. 2. Ілюстрація динамічного характеру локалізації завад

Разом з тим динамічний характер локалізації однієї або декількох завад дозволяє стверджувати, що в кожен окремий момент часу на зареєстрованому зображенні можуть бути як викривлені, так i невикривлені частини зображення, котре асоційоване з біометричним параметром. При цьому 
місцеположення цих частин змінюється. Таким чином, потенційно використовуючи зображення, зареєстровані у різні моменти часу, можливо відтворити незашумлене зображення.

Вказаний постулат дозволяє запропонувати підхід до розробки методу фільтрації біометричних параметрів. В базовому варіанті підхід передбачає розрахунок значень вейвлет-коефіцієнтів кожного iз зареєстрованих зображень, попарну інтеграцію розрахованих значень вейвлет-коефіцієнтів між собою та реалізацію зворотнього вейвлет-перетворення, що призводить до отримання відфільтрованого невикривленого зображення. Зазначимо, що попарна інтеграція вейвлеткоефіцієнтів, здійснена 3 урахуванням необхідності нівелювання завад, може бути реалізована за допомогою одного із принципів:

- 'max' - вибір максимального з двох коефіцієнтів;

• 'min' - вибір мінімального з двох коефіцієнтів;

• 'mean' - вибір середнього значення з двох коефіцієнтів;

- 'img1' - вибір коефіцієнта першого зображення;

- 'img2' - вибір коефіцієнта другого зображення;

• 'rand' - випадковий вибір з двох коефіцієнтів.

Також при створені методу фільтрації використано результати роботи [21], в якій наведено метод вибору найбільш ефективного базисного вейвлету, що відповідає необхідності досягнення достатньої точності спектрального аналізу при мінімальних обчислювальних витратах. Приклад фільтрації зображення обличчя, реалізований відповідно наведеного підходу за допомогою засобів програмного комплексу MATLAB, наведено на рис. 3.

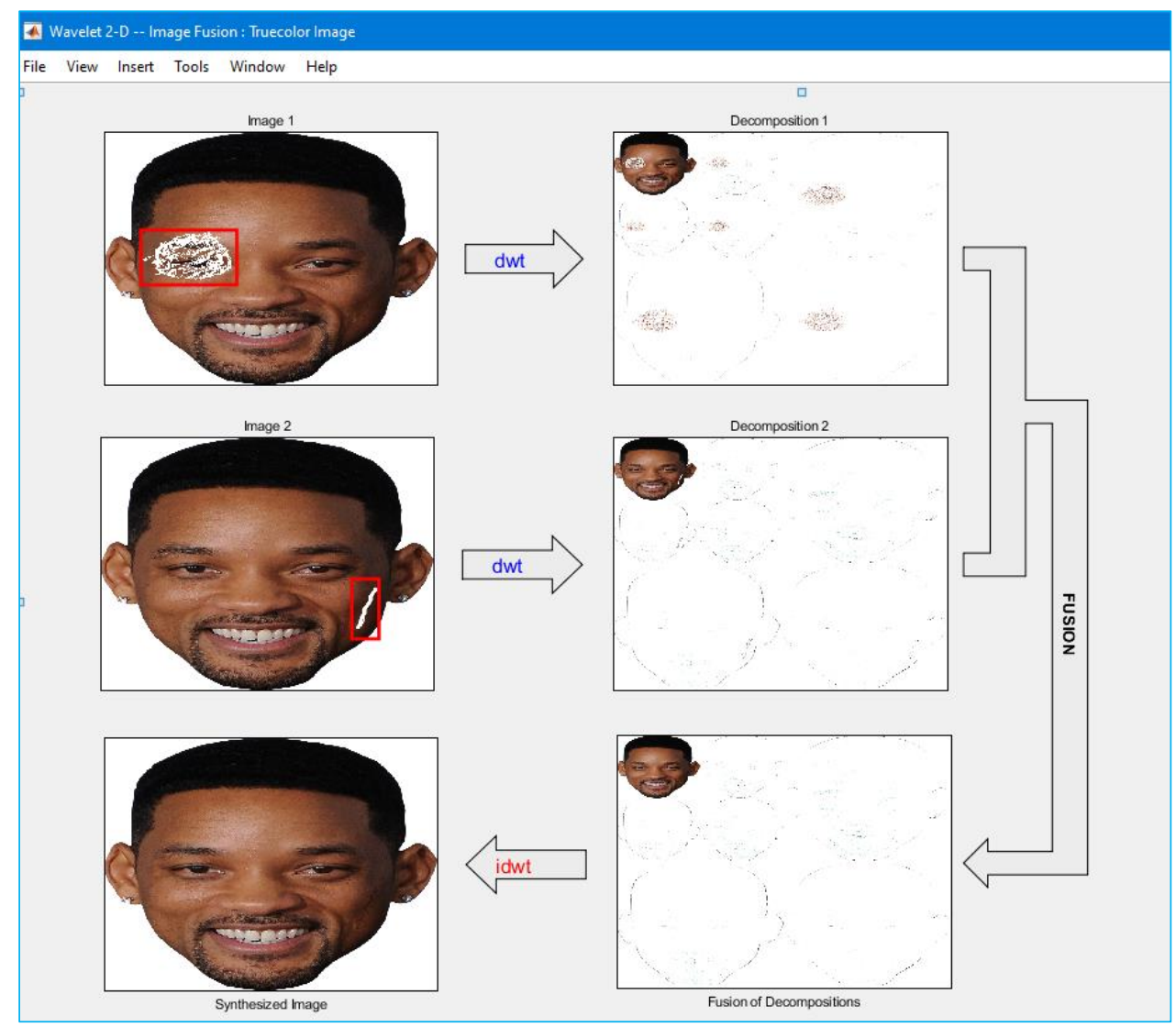

Рис. 3. Приклад фільтрації зображення обличчя засобами MATLAB

Базуючись на запропонованому підході та результатах $[6,12,19,20]$, розроблено метод фільтрації біометричних параметрів, що асоціюються з двовимірними кольоровими або чорно-білими зображеннями. В базовому випадку реалізація методу полягає у виконанні наступних етапів:

1. Провести реєстрацію відеоряду, що відповідає послідовному відображенню зображень, котрі асоціюються з певним біометричним параметром.

2. Визначити перелік типових завад, що притаманні певним біометричним параметрам.

3. Визначити необхідність аналізу кольорового, монохромного (з одним кольоровим каналом) або чорно-білого зображення.

4. Визначити перелік підконтрольних зображень відеоряду, що відповідають зображенням, у яких викривлення локалізовані у різних частинах. 
5. Реалізувати вибір найбільш ефективного базисного вейвлету.

6. Визначити необхідний рівень деталізації вейвлет-перетворень.

7. Розрахувати значення вейвлет-коефіцієнтів кожного із підконтрольних зображень.

8. Обрати принцип інтеграції вейвлет-коефіцієнтів.

9. Попарно інтегрувати розраховані значення вейвлет-коефіцієнтів між собою.

10. Використовуючи отримані значення вейвлет-коефіцієнтів провести реалізацію зворотнього вейвлет-перетворення, що призводить до отримання незашумленого зображення.

Особливості наведеного методу пов'язані з тим, що:

- При реалізації другого, третього та шостого етапів слід враховувати особливості поставленої задачі розпізнавання біометричних параметрів.

- Для визначення найбільш ефективного типу базисного вейвлету можливо застосувати наведений в роботі [21] підхід, в якому обгрунтовано доцільність використання базисного вейвлету, геометрична форма якого найбільш подібна до геометрії процесу, що аналізується. При цьому забезпечується мінімізація обсягу обчислень при вейвлет-перетвореннях та досягається максимальна точність відтворення зображення після зворотнього вейвлет-перетворення.

- При реалізації сьомого та десятого етапів використовуються вирази $(12,13)$ та $(14,15)$.

- Приклад програмного коду процедури інтеграції вейвлет-коефіцієнтів наведено в лістингу 1. Використана мова програмування MATLAB.

Лістинг 1

map $=$ colormap (pink);

mimg=imread('facel.bmp');

mimg $1=$ imread ('face2.bmp');

$X 2=\operatorname{rgb2ind}($ mimg 1, map $)$;

$X F U S=w f u s i m g(X 1, X 2, ' d b 3$ ',9,'min','min')

Програмою передбачено:

- зчитування файлів face1.bmp та face2.bmp,

- використання в якості базисного вейвлету Daubechies wavelet-3,

- рівень деталізації вейвлет перетворень дорівнює 9,

- при інтеграції вейвлет-коефіцієнтів вибирається менший $з$ двох коефіцієнтів.

Проведено експерименти, спрямовані на дослідження запропонованого методу при його застосуванні для очищення від шуму зображення обличчя та радужної оболонки ока. При проведенні досліджень акцентовано увагу на виборі базисного вейвлету. Для прикладу на рис. 4 та на рис. 5 показано зашумлені та відфільтровані зображення обличчя при використанні вейвлету Daubechies wavelet-1 та вейвлету HAAR.

Рис. 6 ілюструє застосування запропонованого методу для фільтрації зображення радужної оболонки ока. Досліджувались прямокутні кольорові растрові зображення обличчя розміром 937 на 689 пікселів, записані в файли формату bmp. Розмір растрових зображень радужної оболонки ока 184 на 274 пікселі. Колір зображення записано у форматі RGB. Завади на зображеннях обличчя співвіднесені з неякісною відеореєстрацією, а завади на зображеннях радужної оболонки ока - 3 відблисками внаслідок нерівномірного освітлення. Для наглядності на рис. 4-6 завади на зображеннях виділені прямокутниками. 


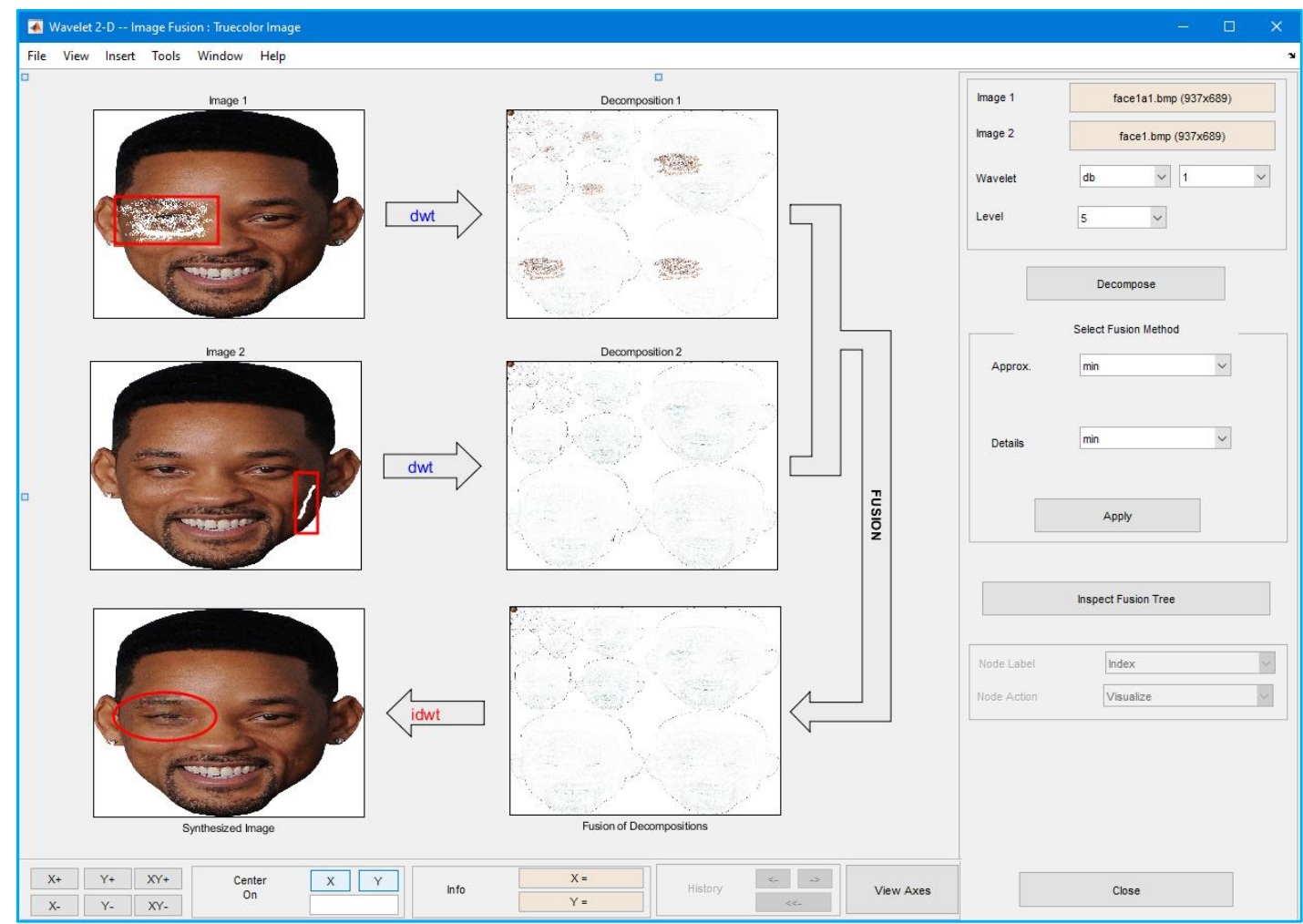

Рис. 4. Приклад фільтрації зображення обличчя з використанням вейвлету Daubechies wavelet-1

Оскільки колір завад був світлішим від кольору зображення обличчя, то в процесі інтеграції обирався менший з двох вейвлет-коефіцієнтів. Зазначимо, що в наведених прикладах при використанні вейвлету Daubechies wavelet-1 рівень деталізації вейвлет-коефіцієнтів дорівнював 5, а при використанні вейвлету HAAR рівень деталізації вейвлет-коефіцієнтів дорівнював 1. Результати експериментів підтвердили дані $[2,11,21]$ про суттєву залежність якості фільтрації біометричних параметрів від типу базисного вейвлету.

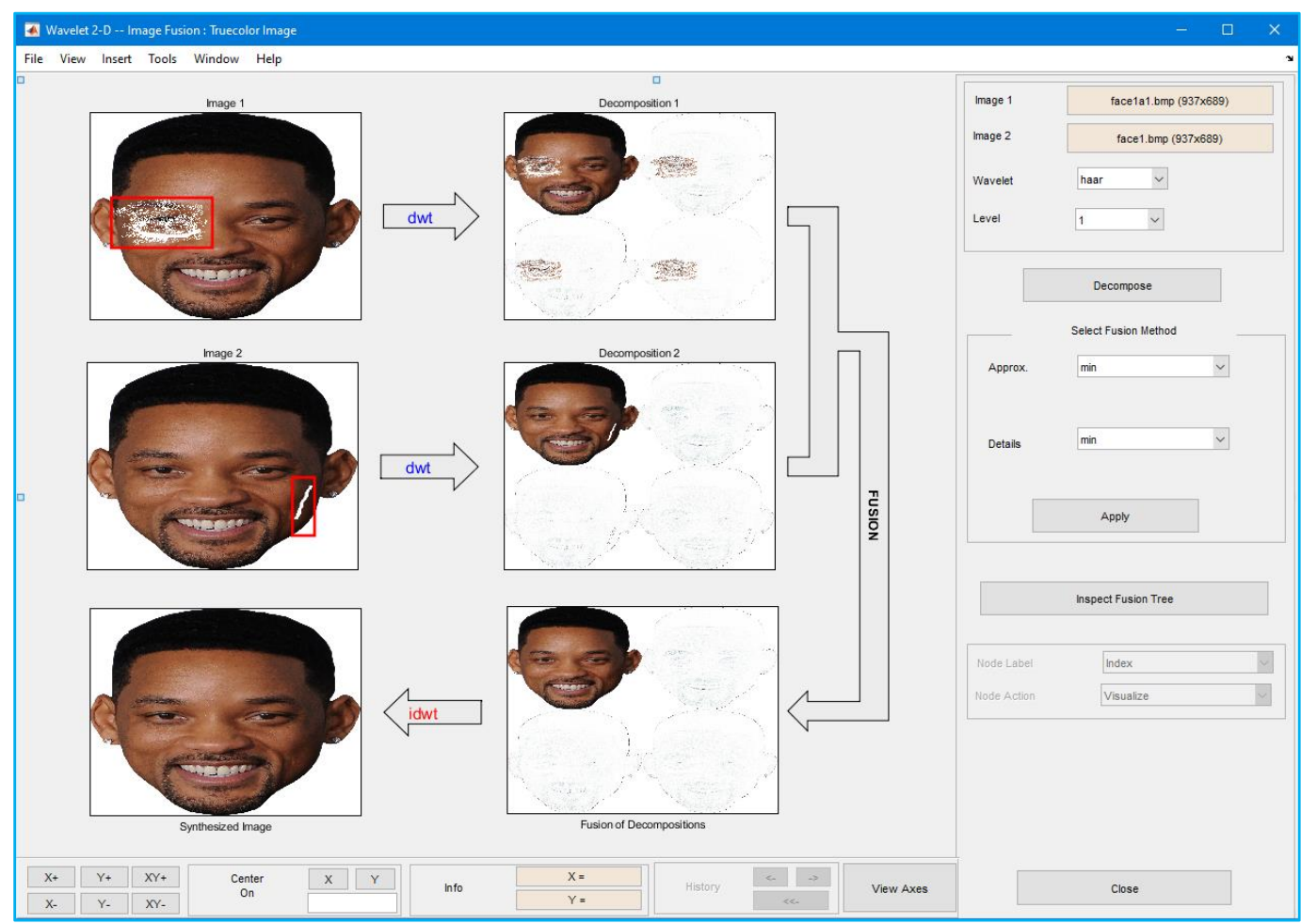

Рис. 5. Приклад фільтрації зображення обличчя з використанням вейвлету HAAR 


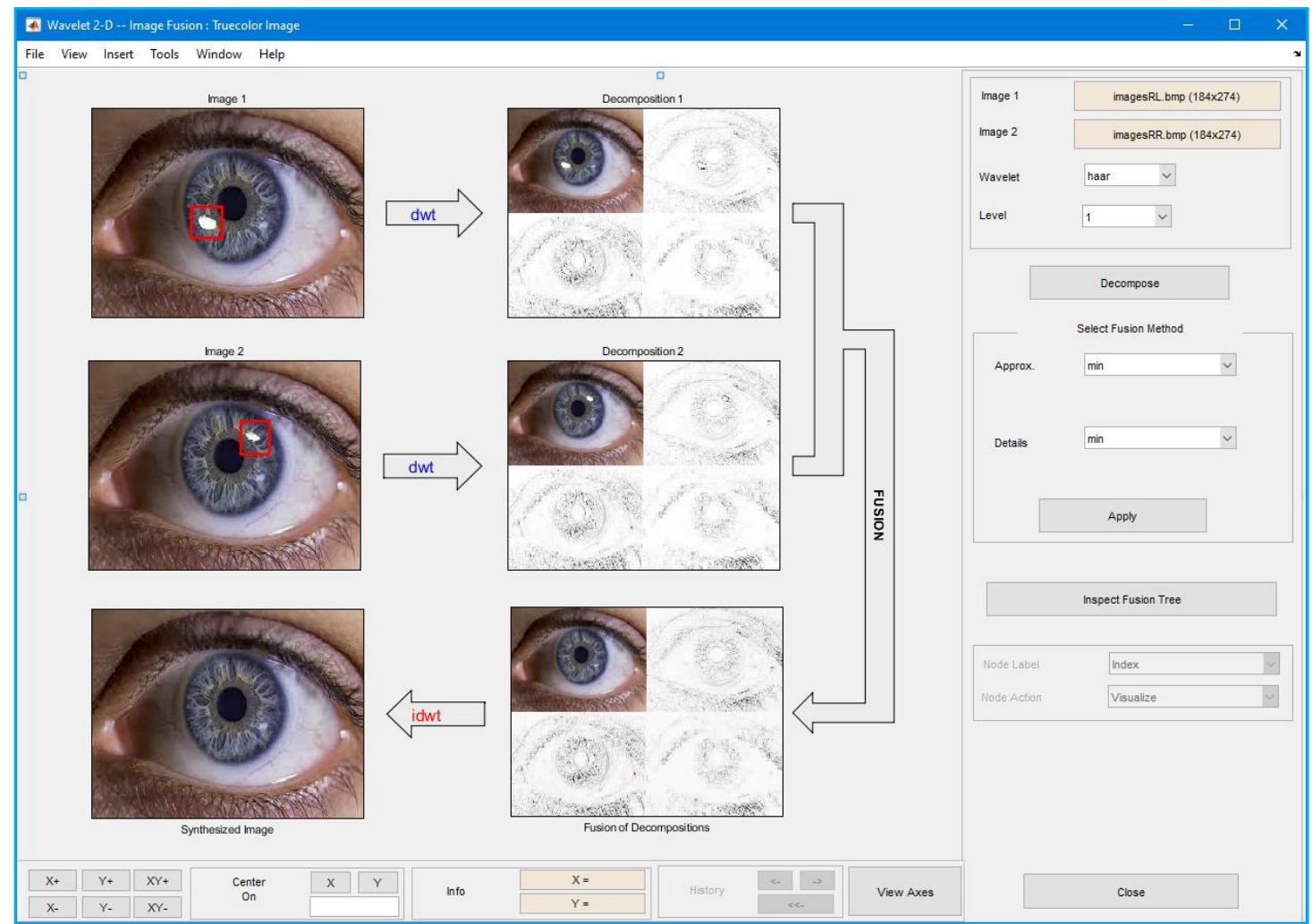

Рис. 6. Приклад фільтрації зображення радужної оболонки ока з використанням вейвлету HAAR

Так, на рис. 4 еліпсом виділена частина зображення обличчя людини, відтворена 3 незадовільною чіткістю після фільтрації з використанням вейвлету Daubechies wavelet-1. Також в результаті експериментів визначено, що з позицій достатньої точності та обчислювальної складності фільтрації найбільш ефективним є використання в якості базисного вейвлету HAAR. При цьому достатньо реалізовувати вейвлет-перетворення 3 рівнем деталізації, що дорівнює 1. Разом 3 тим потребує доопрацювання етап методу, що пов'язаний 3 вибором способу інтеграції вейвлеткоефіцієнтів, що використовується для нівелювання завад локалізованих в різних місцях зображення, асоційованого з біометричним параметром.

Висновки та перспективи подальших досліджень.

Проблематика статті пов'язана з вдосконаленням засобів прихованого моніторингу особи та емоцій операторів інформаційно-управляючих систем на основі біометричних параметрів, що співвідносяться 3 двовимірними зображеннями та характеризуються за допомогою геометричних показників. Показано, що труднощі розробки таких засобів багато в чому пов'язані з очищенням зображень, асоційованих з біометричними параметрами, від типових нестаціонарних завад, викликаних нерівномірністю освітлення та сторонніми предметами, що заважають відеореєстрації.

Визначено перспективність засобів очищення від завад на базі вейвлет-перетворень. Обгрунтовано підхід до розробки методу фільтрації біометричних параметрів, що передбачає розрахунок значень вейвлет-коефіцієнтів кожного із зареєстрованих зображень, попарну інтеграцію розрахованих значень вейвлет-коефіцієнтів між собою та реалізацію зворотнього вейвлетперетворення, що призводить до отримання відфільтрованого невикривленого зображення.

На базі запропонованого підходу розроблено метод фільтрації, який за рахунок застосування запропонованого підходу дозволяє з задовільною якістю реалізовувати їх очищення від типових нестаціонарних завад.

Проведені експериментальні дослідження показали доцільність застосування розробленого методу для фільтрації типових завад на зображеннях, асоційованих з біометричними параметрами операторів інформаційно-управляючих систем.

Запропоновано співвіднести шляхи подальших досліджень з вибором способу інтеграції вейвлеткоефіцієнтів, що використовується для нівелювання завад локалізованих в різних місцях зображення, асоційованого з біометричним параметром.

Список бібліографічних посилань.

1. Биков М.М., Ковтун В.В. Оцінювання надійності автоматизованих систем розпізнавання мовців критичного застосування. Вісник Вінницького політехнічного інституту, 2017, № 2. С. 70-76. 
2. Буй Т.Ч., Спицын В.Г. Разложение изображений с помощью двумерного дискретного вейвлет-преобразования и быстрого преобразования Хаара // Проблемы информатики. 2011. № 2. С. 11-15.

3. Гришенкова Н.П., Лавров Д.Н. Обзор методов идентификации человека по радужной оболочке глаза. Математические структуры и моделирование, 2014, вып. 1(29). С. 43-64.

4. Кемайкин В.К., Арнольдова Е.А. Алгоритм прямого вейвлет-преобразования изображения. Программные продукты, системы и алгоритмы, 2016, №2. С. 1-4.

5. Корепанов А.О. Обнаружение границ радужной оболочки с использованием преобразования Хоу // Вестник Самарского государственного аэрокосмического университета им. Академика С.П. Королёва (Национального исследовательского университета). 2008. № 2. С. 235-239.

6. Корченко А., Терейковский И., Карпинский Н., Тынымбаев С. Нейросетевые модели, методы и средства оценки параметров безопасности интернет-ориентированных информационных систем. [Монография] - К.: Наш Формат, 2016. $-273 \mathrm{c}$

7. Ляхов П. А. Валуева М.В. Применение сглаживающих фильтров для очистки от шума изображений в оттенках серого. Наука. Инновации. Технологии. 2015. № 3. С. 37-50.

8. Міхайленко В. М., Терейковська Л. О., Терейковський І. А., Ахметов Б. Б. Нейромережеві моделі та методи розпізнавання фонем в голосовому сигналі в системі дистанційного навчання: [Монографія] - К.: ЦП «Компринт», 2017.- $252 \mathrm{c}$.

9. Минакова Н.Н., Петров И.В. Параметризация структуры радужной оболочки глаза с использованием вейвлет преобразования. Известия Алтайского государственного университета, 2011. №1. С.105-107.

10. Михайленко В. М., Терейковская Л.А. Парадигмы нейросетевого распознавания эмоций. Управління розвитком складних систем. 2019. №39. сс. 179-186.

11. Нагорнов О.В., Никитаев В.Г. Вейвлет-анализ в примерах: учеб. пособие. М.: Изд-во НИЯУ МИФИ, 2010. С. 405.

12. Путятин Е.П., Кобылин О.А. Использование вейвлет-преобразования для описания контура изображения. Системи обробки інформації, 2004, вип. 1. С. 51-54.

13. Романько О.В. Особенности применения пакета WAVELET TOOLBOX для спектрального анализа сигналов. Системи обробки інформації, 2005, вип. 2. С. 119-126.

14. Рубан И.В., Хижняк И.А. Анализ подходов к идентификации лиц в системах контроля доступа. Наука і техніка Повітряних Сил Збройних Сил України, 2014, № 4(17). С. 67-70.

15. Смоленцев Н. К. Основы теории вейвлетов. Вейвлеты в MATLAB. - М.: ДМК Пресс, 2014. - 628 с.

16. Терейковський I. Нейронні мережі в засобах захисту комп’ютерної інформації.-К.: ПоліграфКонсалтинг, 2007.-209 c.

17. Токмолдин С.Ж. , Клименов В.В., Тулеуов З.Ж., Шакенов К.К. Обработка сигналов с помощью быстрого вейвлетпреобразования на суперкомпьютере в системе MATLAB. Вестник КазНУ, сер. мат., мех., инф. 2012, №3(74). С. 6980 .

18. Третьяков И.Н., Минакова Н.Н. Параметризация структуры радужной оболочки глаза с использованием вейвлетпреобразования. Известия Алтайского государственного университета, 2009. № 1. С. 129-130.

19. Шокуров А.В., Михалев А.В. Оптимальное использование вейвлет-компонент. Успехи мат. наук. 2007. Т. 62, № 4. C. $171-172$.

\section{References.}

1. Akhmetov B., Tereikovskyi I., Tereikovska L., Adranova A. Neural Network User Authentication by Geometry of the Auricle. Recent Developments in Data Science and Intelligent Analysis of Information Proceedings of the XVIII International Conference on Data Science and Intelligent Analysis of Information, June 4-7, 2018, Kyiv, Ukraine, pp.1119.

2. Hu Z., Tereikovskyi I., Tereikovska L., Tsiutsiura M., Radchenko K. (2020) Applying Wavelet Transforms for Web Server Load Forecasting. In: Hu Z., Petoukhov S., Dychka I., He M. (eds) Advances in Computer Science for Engineering and Education II. ICCSEEA 2019. Advances in Intelligent Systems and Computing, vol 938. Springer, Cham. Pages 13-22.

3. Tariq U., Lin K., Li Z., Zhou Z., Wang Z., Le V., Huang T.S., Lv X., Han T.X. Emotion Recognition from an Ensemble of Features. Systems, Man, and Cybernetics, Part B: Cybernetics, IEEE Transactions, 2012, vol. 42 (4), pp. 1017-1026.

4. Tereikovska L., Tereikovskyi I., Mussiraliyeva S., Akhmed G. Recognition of emotions by facial Geometry using a capsule neural network. International Journal of Civil Engineering and Technology (IJCIET). Vol. 10, Issue 04, April 2019, pp. 270-279

5. Tereykovskaya L., Petrov O., Aleksander M. Prospects of neural networks in business models. TransComp 2015. 30 November - 3 December, 2015, Zakopanem, Poland. - P. 1539-1545.

6. Tereikovskiy, I., Parkhomenko, I., Toliupa, S., Tereikovska, L. Markov model of normal conduct template of computer systems network objects // 14th International Conference on Advanced Trends in Radioelectronics, Telecommunications and Computer Engineering, TCSET 2018 - Proceedings. pp. 498 - 501.

7. Toliupa S., Tereikovskiy I., Dychka I., Tereikovska L., Trush A. The Method of Using Production Rules in Neural Network Recognition of Emotions by Facial Geometry. 3rd International Conference on Advanced Information and Communications Technologies (AICT). 2019, 2-6 July 2019, Lviv, Ukraine, Page(s): 323 - 327. 